\title{
PSYCHE.
}

\section{ON SOME GLANDS WHICH OPEN EXTERNALLY ON INSECTS.}

\author{
BY GEORGE DIMMOCK, CAMBRIDGE, MASS.
}

The following paper consists, for the most part, of compiled material lorought into connected form in consequence of ideas suggested to me in studying odoriferous glands of the larvae of Attacus cecropia, to which I have already called the attention of the Cambridge Entomological Club, at its meeting of 13 Oct. 1882. Since that time $I$ have made sections of the above-mentioned glands of Attacus cecropia, and of those which I found later in the larvae of a pterophorid, Aciptilus lobidactylus; the glands of the larvae of these two species have furnished the original descriptive matter of this paper.

'The peculiar odor of the larvae of Attacus cecropia, when they are roughly handled, has probably escaped the notice of but few persons who have reared these moths through their larval stages. If a larva be examined carefully the black spines upon its red, blue, and yellow knobs, or tubercles, will be seen to break easily from the tubercle, and a clear yellow fluid of disagreeable odor to ooze from each opening left by the injury. By crushing the tubercle with a pair of forceps the same strong odor is very noticeable, and by this mode of treatment one has no difficulty in proving that each tubercle, small or large,-blue, yellow or red,-contains the odorous fluid. The red tubercles are seen, in sections cut with the microtome, to be divided into compartments, the cavities of each spine opening into a compartment at its basal end. 'The spines themselves are quite rigid and very brittle, so that they break away at a slight touch and leave a hole in the tubercle, out of which the odorous fluid pours, pushed by internal pressure. This fluid, which I have not examined carefully, but which I hope later to study chemically, is strongly acid to litmus paper, but causes a purple precipitate in carmin solutions. Larvae of Attacus cecropia are provided with these glands and the odorous fluid as early as the third larval stage-perhaps earlier-and apparently shed the glands in the tubercles when moulting the last larval skin in order to enter the pupal state.

The odor given out by the glands of the larvae of Attacus cecropia suggests at once their protective function, and, after having watched a sparrow (Passer domesticus) drag a sphingid larva about, seizing it usually by the horn, it seemed likely to me that the disagreeable acid fluid in the tubercles of the larva of Attacus cecropia was a protection to the larva from similar rough treatment. 
Having found these interesting glands on the larvae of Attacus cecropia, glands concerning which I can find no mention in entomological literature, my attention was drawn further to the subject of external glands of insects, many of which are protective or defensive in function.

Glands similar to those of the larva of Attacus ceeropia, in that they have no outlet until one is produced by external agency, are not rare in the larvae of bombycidce. The severe poisoning produced by the hairs of certain larvae of bumbycidae, of which the so-called processionary caterpillar of Europe is an example, and observed, according to Moufet, ${ }^{1}$ by Dioscorides and other early writers, is caused by the secretion from a minute gland at the base of each hair. The secretion of these glands fills the hollow central portion of the hair, and when the sharp, often barbed, hairs are broken in the flesh of attacking animals, the broken parts carry with them the poisonous secretion. This secretion is, perhaps, formic acid or a formate in solution. Karsten, ${ }^{2}$ in 1848 , described the anatomy of the poison glands at the base of the hairs of an American species of Saturnia. Fine illustrations of this kind of gland are to be found in the stinging hairs of the larvae of Hyperchivia io and Hemileuca maia, both common insects in parts of the United States. Lintner ${ }^{3}$ and Riley ${ }^{4}$ have recorded their experiments on the stinging power of these two species of larvae, and the latter writer has given a list of the larvae of

${ }^{1}$ For literature referred to throughout this paper see the end of the article.
American species of lepidoptera which are known to sting. Lintner has experimented further upon the stinging power of the larvae of Lagoa crispata, and Miss Murtfeldt 5 upon that of the larva of Lagoa opercularis. That the sting of some of these larvae can do lasting injury is certain, for my mother, when twenty-seven years old, received so severe a sting in the middle finger of one hand in brushing away a larva from her neck that the distal joint, healing only after several months, remains somewhat stiffened and slightly deformed, now thirty-seven years. For a time the stinging of these bombycid larvae was attributed to the action of the hairs in entering and wandering about in the flesh, and, even as late as 1881, long after the discovery of the glands at the base of the hairs, Goossens ${ }^{6}$ advances the idea that the poison of the processionary caterpillar of Europe comes from other glands which I shall mention more in detail later. Keller, ${ }^{7}$ in 1883 , discusses the mode of urtication in the processionary caterpillars (larvae of Gastropacha) and figures the glands at the bases of their hairs.

Still another form of gland without any outlet until broken open, but a gland which can scarcely be classed with those previously mentioned, is that at the anterior end of certain bombycid pupae, which breaks when the imago springs the chitinous pupal skin, and leaves its secretion, which has been termed bombycic acid, on the head of the moth, the latter using the secretion to moisten the threads of the cocoon so that they can 
be cut or pushed aside to allow the escape of the imago within. I have never studied this gland and will refer for further notice to the easily accessible papers of Trouvelot, ${ }^{8}$ Packard, ${ }^{9}$ McLaren ${ }^{10}$ and Worthington, ${ }^{11}$ wherein references can be found to earlier European writers on this subject.

It is an easy transition from the glands of the larvae of Attacus, Hyperchiria and Hemileuca, closed by brittle, hollow spines or hairs, to the glandular hairs of certain larvae of pterophoridae, where the hairs are apparently burst open at their tips by the pressure of the secretion within them, the liquid then oozing out to form a dew-like drop upon each hair. Zeller ${ }^{12}$ mentions glandular hairs ("drüsenhärchen”) on the larvae of Mimeseoptilus phaeodactylus and M. mictodactylus, but says nothing of the structure or use of these hairs. Miss Murtfeldt ${ }^{18}$ writes of the larva of Leioptilus sericidactylus "Dorsal hairs proceeding from prominent tubercles, and of two sizes in each tuft, each of the shorter ones tipped with a minute pellucid bead of viscid fluid, to which pollen and bits of leaves often adhere." I have found the larva of Aciptilus lobidactylus to be covered, in like manner, with glandular hairs.

Upon making transverse sections of the larra of Aciptilus lobidactylus, its external surface is found to bear three kinds of appendages. First are the very minute, but obtuse spines (about 0.01 $\mathrm{mm}$. long) which clothe most softer and more flexible portions of its external covering, and which are found on many larvae of different orders of insects.
Second are hairs (from 0.08 to $0.14 \mathrm{~mm}$. long) more or less dumb-bell or club formed, which are filled with granular matter, and seem to be set usually only upon the surface of the chitinous covering of the larva. Third are the longer hairs (from 0.8 to $1.3 \mathrm{~mm}$. long), linear or slightly clavate, usually burst at the tip, or sometimes along the sides, and where burst surrounded by a drop of exuded gummy matter. These last hairs are mounted, by a kind of joint such as is often present at the base of insect hairs, upon or near the summit of little conical elevations, which rise about 0.2 $\mathrm{mm}$. above the surface of the dorsal and lateral parts of the larvae. These hairs are arranged systematically and symmetrically upon the different segments of the larva, the most prominent of them being a pair upon a conical elevation just at each side of the median dorsal line of each segment. A comparison of the arrangement of these hairs and prominences with the arrangement of hairs and warts upon other lepidopterous larvae, especially of those upon the larvae of tortricidae, would be an interesting study. The interior of hairs of this third form opens at the base into the conical prominence or wart on which the hair is situated. The prominence is probably entirely filled by the gland which secretes the viscid matter that finds outlet through the hair.

The specimens of the larva of which I made microtomic sections were not quite well enough preserved to admit of carefully studying the gland at the base of the hairs. The hairs of the second 
and third form seem to be modifications of each other, for, in the longer and more clavate hairs of the second form, the granular matter in the hair extended without interruption into the larva, and these hairs often burst and give out viscid fluid. The larger hairs of the second form are often upon the sides of the conical warts which bear at their summits hairs of the third form. Hairs of similar nature, but smaller and without viscid fluid, clothe the larva of Oxyptilus periscelidactylus and Pterophorus monodactylus.

Mimeseoptilus phaeodactylus feeds on Ononis repens, M. mictodactylus on Saxifraga granulata, Lioptilus sericidactylus on Vernonia noveboracensis and Aciptilus lobidactylus on Solidago ?canadensis: thus, as will be noticed, all the species of plerophoridae mentioned above feed on plants clothed with glandular or long hairs.* The glandular hairs of the larva protect it, probably, by causing it to resemble the surface of the plants on which it feeds, a kind of resemblance not rare in insects; but it is also probable that the secretion of the glandular hairs also protects the larva, to some extent, from the attacks of ichneumons and of other parasites, for I obtained no parasites from over fifty specimens of Aciptilus

\footnotetext{
* Miss Murtfeldt writes me as follows: "I had not thought to mention it in connection with my description of Leioptilus sericidactylus but there is a very close imitation in the dermal clothing of the larva to that of the young leaves of Vernonia, on which the spring and early summer broods feed." ... "Later in the season, when feeding chiefly on the flowers, the larva acquires a purplish tinge which, with the particles of the flowers that adhere to its glandular hairs, is a sufficient disguise from any but the eye practised in its detection."
}

lobidactylus, reared from larvae taken when nearly full-grown, while I have always obtained, in rearing a much less number of Oxyptilus periscelidactylus under similar conditions, several parasites. It is noticeable that the viscid secretion upon the larvae of Aciptilus lobidactylus is alkaline to litmus paper, while the fluid from the tubercles of the larvae of Attacus cecropia is acid.

Turning from the study of insect-hairs which furnish more or less temporary efferent ducts for glands, there are forms of hairs-leaving out of account, as unproved, Weismann's curious, but not improbable, view ${ }^{14}$ that scales of lepidoptera may be sometimes ducts for an odorous fluid secreted by cells at their bases-which are regularly and permanently the outlets for glands at their bases. An interesting example of this kind of open hair duct is furnished by the hairs upon the foot of the common house-fly (Musca domestica), throngh which hairs, as recently shown by Dewitz, ${ }^{15}$ a sticky secretion is poured, the fly being enabled by the adhesion of this secretion to rest upon smocth vertical surfaces. Ley dig, ${ }^{16}$ in 1859 , describes and figures glands in the tarsi of several coleoptera; West, ${ }^{17}$ in 1862, describes and figures the tar'sal hairs of the fly and of many other insects ; and Dewitz, ${ }^{18}$ in 1882 , discusses the function in locomotion of the viscid secretion which is discharged by the glands of the foot through the tarsal hairs, both in flies and in coleoptera.

Defensive glands of another kind, the ducts of which open into spines, are the 
glands which furnish the poisonous secretion for the sting of bees and wasps. I have not discussed these glands further in this paper, because they are rather internal than external glands; for like reasons I have not referred to the silkglands of lepidopterous and hymenopterous larvae. The literature of importance upon the subject of the silk-glands of lepidoptera can be found in a dissertation by Helm, ${ }^{19}$ in 1876 ; and papers by Dewitz, ${ }^{20-21}$, in 1875 and 1877 , and by Forel, ${ }^{22}$ in 1878 , give a clue by which to trace the literature upon the stinging organs of hymenoptera.

The glands of the larva of Attacus cecropia and Hyperchivia io, sealed until broken open by some external agency, may be termed passive glands, while those glands which pour out their secretion in direct response to some voluntary or reflex action of the insects, as do the foot-glands of Musca, the sting of the bees and many other glands, may be termed active glands. But there are glands characterized by still greater activity than those already mentioned. If the larvae of certain species of Cimbex are suddenly disturbed, they will jet cut, as observed by Bonnet ${ }^{23}$ (v. 1, p. $470,473,485)$, a clear yellow fluid, of disagreeable odor, from openings along their sides. In the case of a German species of Cimbex I have seen this fluid thrown by the larva to a distance of several centimetres, altho Frisch, ${ }^{24}$ who first mentions this secretion, in 1736 , apparently only saw it flow from the openings.

Upon disturbance, the larva of the
European bombycid, Harpyia vinula, raises its head and jerks it from side to side, throwing a strongly acid fluid from a gland, the opening of which is on the ventral side of the first thoracic segment. The propulsion is here partly produced by the rapid jerking of the head, and partly by pressure upon the receptaculum or lumen of the gland within the body. This gland, or at least its secretion, was noticed by de Geer ${ }^{25}$ in 1750, and more fully in 1755 by Bonnet, ${ }^{26}$ who described the secretion as a true acid, sharp, sour, and biting. Later, besides many brief notes on this gland, may be mentioned more extended descriptions by Müller, ${ }^{27}$ Amoreux, ${ }^{28}$ Jördens, ${ }^{29}$ and Rengger. ${ }^{80}$ I have not observed whether the larvae of the common American species of Harpyia (Cerura) possess this power of throwing a defensive fluid or not, and Lintner, ${ }^{81}$ as well as French, ${ }^{82}$ in descriptions of the American larvae, make no mention of such power. The soft skin of the larva of Harpyia vinula evaginates itself about the orifiice, on the first thoracic segment, where the gland discharges its fluid, forming four points which are well figured by Müller and Jördens, in the books cited above. Within, the duct of the gland passes to the right of the displaced central nervous system, as described and figured by Mrs. Dimmock, in Psyche, v. 3, p. 340-341.

I pass by, with mention only, the openings which pour out an odorous yellow fluid from the joints of the legs of species of coccinellidae, chrysomelidae and meloidae, for further notice of which I refer to papers by Leydig' ${ }^{16}$ (p. 37-38) 
who thought the fluid to be only the blood of the insect; the glands opening between the prothorax and head and between the mesothorax and metathorax in dytiscidae, of which the nature of the secretion has been somewhat studied by Plateau $^{33}$; the anal glands of Brachinus and other carnivorous coleoptera, the explosive mode of whose discharge in Brachinus has given rise to its popular English name of bombardier, for the literature of which I refer to Leydig ${ }^{16}$ (p. 46-49), and to a late paper by Rougement ${ }^{34}$; the cornicles of the sixth abdominal segment of aphidae, which are supposed to pour ont a sugary material sought by ants, but which material Witlaczil ${ }^{35}$ writes, in a paper to which I will refer for further literature of the anatomy of aphidae, comes from the anus of these insects; $*$ the sacs, probably glandular in function, found by Hagen $^{36}$ upon the larvae of certain neuroptera ; the odoriferous glands of hemiptera mentioned by Landois ${ }^{40}$ and others ; the scent-glands which Aube ${ }^{41}$ mentions on the elytra and thorax of Eumolpus pretiosus; the wax-secreting glands found on certain insects, treated of by Claus, ${ }^{42}$ in 1867; and the odoriferous glands of phasmidae described by Scudder, in Psyche, v. 1, p. 137-140:-all these glands I pass by, giving reference only

*Buckton, 37 in vol. $\mathrm{r}$, of his Monograph of British aphides, discusses (p. 39-47) "honey dew" of aphidae as well as (p. 37-38) various waxy and silky secretions with which hemiptera cover themselves. I may add here that Gentry's ${ }^{33}$ observation, in 1874 , that young aphi. dae suck the secretion of the cornicles of older ones is anticipated by Morren, 39 in 1836 , and Morren adds to his statement "fait observé déjà par Bonnet"-fact already observed by Bonnet. to some papers which will guide further to the literature of the subject, in order to come directly to forms of which the morphology is more interesting in this connection, or of which the function is not so well understood.

An interesting economical provision is evident in the odoriferous tubercles of the larvae of Attacus cecropia and in the urticating spines of Hyperchiria io. There is no waste of the secreted material by either of these larvae; it is sealed up until its use is necessary and then it is applied exactly where it will accomplish most. But what shall one say of the novel mode of avoiding waste, to which attention was called by Claus, ${ }^{43}$ in the larva of the European chrysomelid, Lina populi? Along the dorsal side of this larva are rows of short black spines, not noticeably different from the spines often found on larvae of coleoptera, but if the larva is disturbed it will suddenly press ont upon the tip of each of the spines a spherical drop of milky liquid. Watch these drops for a moment. As the disturbance which has caused their appearance subsides, they become smaller, sometimes suddenly, sometimes gradually, but always in unison, until finally, when the larva no longer feels itself in danger, the drops entirely disappear: the fluid has been drawn back into the spines to be used again in case of need. Claus has suspected that salicylic acid exists in the secretion from the larva of Lina populi, which is very probable, since the larva feeds upon leaves of Salix and Populus, that contain salicin, of which 
salicylic acid is an oxidation-product. Claus says that the larva of Lina populi has been used as a source of salicylic acid in small quantities. The odorous secretion of the glands of the larva of Lina protect not only the larva, but, as Lyonet noticed, also the pupa, from the attacks of birds. Claus shows how this protection of the pupa is accomplished: the glands, with their contents, are shed with the last larval skin, which remains around the point of attachment of the abdomen of the pupa, and, when the latter wriggles about on account of any disturbance, the odorous fluid is squeezed from the molted glands. De Geer ${ }^{45}$ describes and figures the spines of the larva of Lina populi in 1775. Lyonet, ${ }^{44}$ probably somewhat earlier, describes and figures the larvae of Lina populi and $L$. dor:alis, and mentions the protrusion and retraction of the milky drops. Ratzeburg ${ }^{46}$ mentions briefly the glandular secretion of $L$. populi, and Westwood $^{47}$ collects together notes on the larvae of different species of Lina. Chapuis and Candèze ${ }^{48}$ write that the larva of Lina (Plagiodera) scripta from the United States is similar to that of L. populi.

Claus $^{43}$ was the first to study the internal anatomy of the glands and spines of Lina populi, and he shows that the liquid is pushed out of the spines by a contraction, which I may be allowed to term an incipient evagination, of the walls of the gland. This leads one to search further in order to find if this principle of evagination of glandular walls is not carried to a greater extent in other insects. Little search reveals numerous forms of glands in which a part or the whole of the duct, or the glandular surface itself is evaginable. This form of gland is not confined to any one order of insects; altho first found in lepidopterous larvae, glands of this form have since been found in imagos of lepidoptera, coleoptera and orthoptera. The latest writer who has dealt especially with this kind of glands is Klemensiewicz, ${ }^{49}$ in 1883.

In this group of glands or gland-like organs may be classed the evaginable osmateria of the larvae of Papilio, the protrusile tails or modified anal legs of the larva of Harpyia (Cerura), the lateral appendages of Malachins, certain evaginalle appendages upon the eleventh and twelfth segments of the larvae of some species of Lycaena, lateral evaginable appendages in a species of Corydia, the red protrusile warts upon the dorsum of the larva of Orgyia, the evaginable warts of some of the stinging larvae of bombycidae, the evaginable appendages of various forms near the anus of certain imagos of lepidoptera and coleoptera, the organs on the ventral side of the first thoracic segment of many lepidopterous and of a few phryganeid larvae, and the protrusile organs near the anus of larvae of Myrmeleon.

Organs of the sort now under consideration were first mentioned in 1602 by Aldrovandus, ${ }^{50}$ who observed and roughly figured osmateria on the larva of Papilio. Frisch ${ }^{24}$ (Theil 2, p. 41-42), in 1721 , describes the osmateria of the 
larva of Papilio machaon, which he says "protect it from its enemies, not by their strength, for they are hollow and delicate lobules, but by the stench which comes from them. Madame Merian calls it a pleasant odor ( 2 d ed., pt. 1, n. 38 ) but I find it intolerable." Since the time of Frisch many authors have described the osmateria of different species of Papilio, among them Karsten, ${ }^{2}$ who described, in considerable detail, the anatomy of these organs in Papilio asterias. He says they discharge "a substance, strongsmelling like butyric acid, by which they scare away their enemies; this substance reddens litmus readily, produces white clouds when brought near strong ammonia, has a somewhat biting acid but not unpleasant taste. Mixed with water, oil-like drops are seen under the microscope; neutralized with ammonia it crystallizes." The crystals "are not volatile upon raising the temperature but decompose with disengagement of empyreumatically smelling vapors. Caustic baryta dissolves the acid, the salt crystallizes in groups of very fine needles." For the anatomy and histology of the osmateria of the larvae of Papilio I will refer to Karsten ${ }^{2}$ and Klemensiewicz. ${ }^{49}$

Each of the two caudal appendages of the larva of Harpyia consists of a basal tube which projects backward from the posterior end of the larva, but which can be turned somewhat upward and forward. Out of the tip of each of these basal tubes a reddish filament can be evaginated, which the larva, upon the approach of danger, curves above the body and waves with a trembling motion seeming often to whip the whole surface of its bory. These threads or filaments are probably evaginated by internal pressure of the fluids of the body, but are retracted by muscles within them. 'There is some doubt whether these threads are really glands, and Frisch ${ }^{24}(1740$, Theil 6, p. 18-19), who expected to find them odorous, writes that the odor "must be very subtile and be only perceptible, for the most part, to insects hostile to this larva"; but, if these filaments are not glands, they have the same coarser anatomy and should be considered here.

The earliest description of the evaginable caudal appendages of Harpyia that I have seen is that by Goedart, ${ }^{5}$ who says of them "This larva has two tails and when it is vexed, it will throw out from both tails a red rod or sting, which it bends back, and, as if mad, vibrates formidably, and draws it back in again." Since Goedart's time these appendages have been described by Réaumur, ${ }^{52}$ Frisch $^{24}$ (Theil 6, p. 18-19), de Geer ${ }^{45}$ (Bd. 1, tab. 23, fig. 12), Bonnet, ${ }^{26}$ Müller $^{27}$ ( . 28-30), Jördens, ${ }^{29}$ Meckel, ${ }^{58}$ Klemensiewicz, ${ }^{49}$ and others. Some of these authors also describe the gland previously mentioned (p. 391), as opening upon the under side of the first thoracic segment of the same larva, and Schäffer, ${ }^{54}$ in 1754 , first shows the intimate relationship of this gland to evaginable glands found in the same position on larvae of other species, to the osmateria of the larvae of Papilio, and in general mode of action to the evaginable glands of Malachius.

The evaginable organs of the imago of 
Malachius consist of a pair of reddish, trilobed organs, one on each side, between the head and the first thoracic segment, and a similar, but somewhat larger pair of bilobed organs, one on each side, between the metathorax and first abdominal segment. These organs are protruded by the fluids of the bodycavity, but have muscles for their retraction. These organs were mentioned by Schäffer ${ }^{54}$ in 1754 , by Sulzer ${ }^{55}$ in 1761 , and since that time more or less discussed by Kirby and Spence ${ }^{56}$ (in whose work may be found much that is important and interesting on the glands and odors of insects), by Westwood, ${ }^{47}$ Laboulbène, ${ }^{57}$ Liegel, ${ }^{58}$ Klemensiewicz, ${ }^{49}$ and by others whose papers I cannot at present cite, as I have not collected the literature of this part of my subject with much thoroughness. The function of these organs of Malachius is not determined with certainty.

The larvae of certain species of $L y$ caena have been found to attract ants, on account of an opening upon the dorsum of the eleventh segment, which gives out a liquid apparently containing sugar. Upon the twelfth segment, and evidently connected in function with the opening above mentioned, are two protrusile organs covered with fine hairs. 'The fact of ants being attracted to these larvae was first observed, so far as I can learn, by Esper; Petzhold, ${ }^{59}$ in 1793, figured, and described with considerable minuteness, the appearance of the protrusile organs on the twellth segment of Lycaena biton, and mentions their occurrence on the larvae of other species.
Guenée, ${ }^{60}$ in 1867 , describes and figures these organs in Lycaena boetica. W. H. Edwards, ${ }^{61-62}$ in 1878, described and figured similar organs on Lycaena pseudargiolus and $L$. comyntas, American species. Scudder, ${ }^{63}$ in 1881 , repeats Edwards' figures, referring however to Guenée as the discoverer of these organs. The function and structure of the evaginable organs of the larva of Lycaena are not yet settled.

Evaginable organs were described from a blattid, Corydia carunculigera, by Gerstaecker ${ }^{64}$ in 1861. The organs of Corydia are yellowish white, covered with hairs, and there are two of them on each side of the insect, evaginable from between the dorsal and ventral plates of the first and second abdominal segments. These organs are present in both male and female, but are not found in the larva of Corydia. Gerstaecker suspected them to be of glandular nature. Brunner von Wattenwyl, ${ }^{65}$ in 1879 , described an evaginable organ on the femora of acrididae; Burgess gives an abstract of his paper in Psyche, v. 3, p. 32. These organs in acrididae and those of Corydia are the only eraginable organs of which I have found mention in orthoptera.

The larvae of European species of $\mathrm{Or}$ gyia (e.g., of $O$. aurifua) have long been known to have evaginable warts upon their dorsum. Brief notice of these warts will be found in works of Schwarz, ${ }^{66}$ Jördens, ${ }^{29}$ Klemensiewicz, ${ }^{49}$ and other writers, but I have found only the slightest allusions to them in American species. Fitch $^{67}$ in describing the larva of $O$. nova, mentions them; Coleman, ${ }^{68}$ in describ- 
Ing the larva of $O$. leucostigma, terms them "coral-red retractile warts"; and Coquillett, ${ }^{69}$ in describing the larva of Parorgyia clintonii, speaks of them as "reddish warts" without adding that they are retractile.

Evaginable warts similar to those upon the dorsum of Orgyia are present on different parts of various bombycid larvae, and Klemensiewicz ${ }^{49}$ has described their structure in Leucoma salicis. I have mentioned their occurrence in $H y$ perchiria io on p. 352-353 of Psyche, v. 3 , and they seem especially abundant on stinging larvae. Groossens ${ }^{6}$ regards the spines of the larvae of Cnethocampa to be poisonous because of a powder produced by the drying of the secretion given out by the evaginable glands upon the dorsum of these larvae. 'This view seems inacceptible after Karsten, ${ }^{2}$ Keller ${ }^{7}$ and other's have so clearly proved the presence of glands at the bases of the spines of these stinging larvae.

The structure of the evaginable warts and their glands in Leucoma salicis is well described by Klemensiewicz, ${ }^{49}$ and will answer in a general way for the similar warts of Orgyia and of the European Liparis. The wart is protruded by pressure of the fluids within the body and retracted by muscles; at or near its centre open the ducts of one or two glands which are situated beneath the warts. The position and general structure of these glands, as well as their motion when the larvae are disturbed, indicate that they are defensive in function, but exact observations are still lacking on this subject.
In quite a number of staphylinidae, and more rarely in other beetles, there is a pair of evaginable organs, one on each side of the anal opening, which give off a disagreable odor when protruded, and which must have attracted the attention of most collectors of coleoptera in capturing the larger species of staphylinidae. They have been mentioned or described by Schäffer, ${ }^{54} \mathrm{Du}$ four, ${ }^{70}$ and Leydig ${ }^{16}$ (p. 52-õ3). The function of these organs is evidently defensive.

Similar appendages, but often more striking on account of their greater size, have been found in several lepidoptera, in most cases American species, altho the first mention of these organs in lepidoptera also dates back to Schäffer, ${ }^{54}$ in 1754. I have given an outline of the bibliography of this subject, as far as it concerns the species of lepidoptera found in this vicinity, in Psyche, v. 4, p. 59, and need not repeat it here. Fritz Müller, ${ }^{71-74}$ has contributed several paper's (in 1874, 1877, and 1883) to this subject. Doubleday ${ }^{75}$ (1846-1850) called attention to the presence of such organs in butterflies of the genus Acraea.

These organs are sometimes naked and sometimes clothed with hairs or scales. The long yellow organs protruded by Spilosoma acrea are good examples of the hair-clothed form, while the organs described by Fritz Müller in Heliconius and allied genera are covered with scales. The function of all these organs is not yet determined, but it is certain that a part of them at least are for the distribution of odor. 
Mention has been made already twice of the gland which opens beneath the first segment of the larva of Harpyia vinula. In the same position on many larvae, some of those of Vanessa, Melitaea, Argynnis, Bryophila, Cucullia, Habrostola, and Cleophane, according to Rogenhofer ${ }^{76}$; and of Aporia, many satyrids, Aplecta and Leucania, according to Goossens ${ }^{77}$-is an evaginable portion, which, in some cases, probably in all, is glandular, but the function of which is entirely undetermined except in the case of Harpyia vinula, where it is an organ of defense. These organs were compared to the osmateria of Papilio larvae by Schäffer, ${ }^{54}$ and have been more or less discussed by Rogenhofer, ${ }^{76}$ Lacordaire, $^{78}$ Goossens ${ }^{77,79}$ and Klemensiewicz. ${ }^{49}$ Bonnet ${ }^{80}$ discovered these organs in 1739 , altho he published nothing about them, as far as I know, until 1755, a year after the paper mentioned above was published by Schäffer. Bonnet gives a list of thirty-one caterpillars which possess these organs, and he tried experiments to see if cutting off these organs in larvae affected in any way the imago produced from them, proving that imagos from larvae thus treated were perfect. Bonnet ${ }^{23}$ (p. 503-504) also found two evaginable fleshy organs near the posterior extremity of the abdomen in the larva of the ant-lion (Myrmeleon).

Réaumur $^{52}$ (1737, tome 3, p. 165), notices an organ, probably similar to that under the first thoracic segment of certain lepidopterous larvae, in the same locality, on a phryganeid larva, and Rogenhofer, ${ }^{76}$ mentions, on the authority of Brauer, a protrusile organ beneath the first segment of a phryganeid larva.

In dealing with the protrusile organs of different insects above, I have given more citations of early authors than I should have done had I found them brought together elsewhere. Klemensiewicz, altho not claiming to give the full literature of the subject, certainly omits, and apparently has not seen, some of the more important papers on the subject of which he treats. I have mentioned only the more important papers on the glands of European insects, but I have songht to refer to all papers which have dealt originally with evaginable glands of A merican insects.

I have not examined carefully the papers published upon the subject of femoral tufts of lepidoptera, or tufts upon other parts of lepidopterous insects; which tufts I presume may well come into consideration at this point. Fritz Müller ${ }^{81}$ treated of them at some length in 1877 . They have been suspected often to be organs for the distribution of odors, and Bertkau $^{82}$ has shown, in one case - that of the male of Hepialus hecta - that the analogous tibial organ is filled with glands, and is used, in connection with organs on the first abdominal segment, to diffuse an odor for sexual purposes. These organs of Hepialus are noticed more fully than here, by Burgess, in Psrche, v. 3 , p. 32.

A few considerations upon the use to which the different forms of glands, so briefly noticed in this paper, especially adapt themselves may be appropriate in closing this paper. The simple glandu- 
lar opening is not economical for the application of odorous, ill-tasting or irritating fluids. If it is provided with means for throwing its secretion, as it is in Cimbex and Harpyia, it is somewhat more efficient at long range. The chances, however, of a waste of the secreted matter are still great, and, as Jördens has observed, the larva of Harpyia uses its stream-throwing gland only when much disturbed. For the application of an ill-tasting fluid the modified form of gland found in the knobs of the larva of Attacus cecropia seems to be the best. 'The secretion is set free by the very action of the enemy of the larva. 'The use of a strongly irritating fluid attains its highest development in means of injecting the fluid into the flesh of the attacking animal, as is done by Hyperchiria and by many hymenoptera. 'The greatest economy in the use of an odorous fluid is attained by exposing suddenly a large surface moistened with the fluid to the surrounding air. This is accomplished by osmateria, as in the larvae of Papilio, and by various evaginable appendages, in other insects. Clothed with hair these appendages expose still more surface to the air, and thus give still better results in rendering the surrounding air odorous, whether for protective or for sexual purposes. For sexual purposes a less penetrating, often to us a less disagreeable, odor, and less of it, is necessary than for protective purposes. It is perhaps for this reason that the evaginable appendages of Spilosoma, and of some other lepidoptera, appear to us always dry. The reason for the invagination of odor-distributing appendages is a double one ; first when invaginated their necessarily delicate surface is less liable to injury, and, second, their surface can be kept constantly moistened and ready for use without loss of the odorous fluid. Besides this, too, is the general rule that the appendages of locomotory animals are, as far as is possible in attaining the purpose for which they are developed, normally invaginated or retracted to avoid hindrance to locomotion, while the corresponding organs of sessile animals and plants attain their surface-development by evagination.

Secretions which are intended to protect by their odor usmally protect by their taste also, for taste and smell are so nearly related senses in higher animals, while such glands as secrete ill-tasting fluids, if these fluids are volatile, also usually protect by their odor. Still it may be safely asserted, as a general rule, that odor protection is accomplished by evaginable organs.

The chemical substances proved by actual test to be secreted by external glands of insects are few in number, and, as I hope sometime to make this the subject of a special paper, I should be glad to have my attention called to any secretions of insects, especially to such as can be obtained in sufficient quantity for chemical examination.

In the preceding notes I have sought to call attention to glands of insects, in hope that some American students of insects, who have not enlister already in that army of species-describers, which represents so-called American entomo- 
$\log y$ by a probable majority, may be induced to turn their attention to the anatomy, biology or physiology of American insects. The study of the general anatomy of insects can be pursued in any country, but there always remain special points in the anatomy of insects, of which points glands and similar modifications of parts of insects for special purposes form no small part, wherein insects of one country differ from those of any other. In such fields of study as these young American entomologists can compete most successfully with European anatomists and can make important discoveries, and to researches of this kind future entomologists who have aspirations to become more than locally known must turn their attention. Leave the creation of scientific names, quarrelling over synonyms among them, and search for new spe ies, to the antiquated type of naturalists who have become so habituated to studying the exterior of their insects that to "destroy" a rare specimen by dissecting it has become a crime to them. In their regard for the exterior of animals, coupled with their crude knowledge of internal anatumy, they remind me of Romans, who makes a grave statement in his history of Florida (p. 55 ), that "Anatomy has taught us, that the bone of a negroe's skull, is always black."

\section{LITERATURE.}

${ }^{1}$ Moufet, $\mathrm{T}$ : Insectorum sive minimorum animalium theatrum . . Lond., r634. p. I85- 186 .

${ }^{2}$ Karsten, H. Bemerkungen über einige scharfe und brennende absonderungen verschiedener raupen. (Archiv. fur anat., phys. u. wiss. med. 1848, p. 375-382, pl. I I-I2.)
${ }^{3}$ Lintner, J. A. Entomological contributions, 1872 : no. I, p. II-I2; no. 2, p. 36-37.

${ }^{4}$ Riley, C: V. Fifth report state entom. Missouri, I873, p. 125-126, 131, I34.

${ }^{5}$ Murtfeldt, Miss M. E. An experiment with a stinging larva. (Can. entom., Nov. 1876, v. 8, p. 201-202.)

${ }^{6}$ Goossens, Th. Des clfenilles urticantes et quelques considérations sur l'utilité des œufs pour la classification. (Ann. soc. entom. France, I88i, s. 6, t. I, p. 231-236.)

${ }^{7}$ Keller, C. Die brennenden eigenschaften der processionsraupen. (Kosmos, I883, bd. 13. p. 302-306, fig.)

${ }^{8}$ Trouvelot, L: The American silk worm. (Amer. nat., 1867 , v. r, p. 30-38, 85-94, 145ז49, il.) p. 33 .

${ }^{9}$ Packard, A. S., jr. The mode of extrication of silkworm moths from their cocoons. (Amer. nat., June I878, v. [2, p. 379-383, fig.)

${ }^{10}$ McLaren, D. C. The mode of extrication of the American silk-worm moth. (Amer. nat., July i 878, v. 12, p. 454-456.

${ }^{11}$ Worthington, $\mathrm{C}: \mathrm{E}$. On the emergence of lepidoptera from their cocoons. (Can. entom., Aug. I878, v. IO, p. I58-159.)

${ }^{12}$ Zeller, P. C. Revision der pterophoriden. (Linnaea entom., I852, v. 6, p. 319-4I6.) p. 356 .

${ }^{13}$ Murtfeldt, Miss M. E. New plume moths, pterophoridae. (Amer. entom., Oct. I88o, v. 3, p. 235-236.)

${ }^{14}$ Weismann, A. Ueber duftschuppen. (Zool. anzeiger, 26 Aug. I878, jahrg. I, p. 98-99.)

${ }^{15}$ Dewitz, H. Wie ist es den stubenfliegen und vielen anderen insecten möglich, an senkrechten glaswänden emporzulaufen? (Sitzungs-ber. gesells. naturf. freunde zu Berlin, I7 Jan. I 882 , p. 5-7.)

${ }^{16}$ Leydig, F. Zur anatomie der insecten. (Archiv. f. anat., phys. u. wiss. med., r 859, p. $33-89$, 149-1 83 , pl. 2-4.) p. 35 and 38 .

${ }^{17}$ West, T. The foot of the fly; its structure and action: elucidated by comparison with the feet of other insects, \&c. (Trans. Linn. soc. Lond., 1862, v. 23, p. 393-42 I, pl. 4I-43.)

${ }^{18}$ Dewitz, H. Ueber den kletterapparat der insekten. (Sitzungs-ber. gesells. naturf. freunde zu Berlin, I8 July ı882, p. Io9-I13.)

${ }^{19}$ Helm, F. E. Ueber die spinndrüsen der lepidopteren. (Zeits. f. wiss. zool., I876, bd. 26, p. 434-469, pl. 27-28.)

${ }^{20}$ Dewitz, H. Ueber bau und entwickelung 
des stachels und der legescheide einiger hymenopteren und der grünen heuschrecke. (Zeits. f. wiss. zool., 187.5 , bd. 25 , p. I74-200, pl. I2-I3.)

${ }^{21}$ Dewitz, H. Ueber bau und entwickelung des stachels der ameisen. (Zeits. f. wiss. zool., i 877 , bd. 28, p. 527-556, pl. 26.)

${ }^{22}$ Forel, A. Der giftapparat und die analdrü e l der ameisen. (Zeits. f. wiss. zool., 1878, bd. 30, suppl., p. 28-68, pl. 3-4.)

${ }^{23}$ Bonnet, $\mathrm{C}$ : Observations diverses sur les insectes ... (Collection complète des œuvres de C: Bonnet, t. I, p. 259-574 [+2 p.], pl. $\mathrm{I}-6$.

${ }^{24}$ Frisch, J. L. Beschreibung von allerley insecten in Teutschland . . . 1736, th. 4, p. 44 .

${ }^{25}$ DEGeer, C. Observation sur la propriété singulière qu'ont les grandes chenilles à quatorze jambes et à double queue, du saule, de seringuer de la liqueur. (Mém. sav. étrang. Paris, I75o, t. I, p. 530-5.3 I, pl.)

${ }^{26}$ Bonnet, C: Mémoire sur la grande chenille à queue fourchue du saule, dans lequel on prouve, que la liqueur que cette chenille fait jaillir, est un véritable acide, et un acide très-actif. (Mém. math. d. savants étrang. Paris, I75.5, t. 2, p. 276-282.) (Collection complète des œuvres de C : Bonnet, 1779, t. 2, p. I 7-24.)

${ }^{27}$ Miller, O. F. Pile-larven med dobbelt hale, og dens phalaene . . Kjöbenhavn, I 772. p. 53-56, pl. 2, fig. 3-5.

${ }^{28}$ Amoreux, P. J. Notice des insectes de la France, réputés venimeux, . . Paris, I789. p. $282-285$.

${ }^{29}$ Jördens, J. H. Entomologie und helminthologie des menschlichen körpers . . Hof, I8OI, bd. I, p. IOI-IO2, pl. I2, fig, 6-8.

${ }^{30}$ Rengger, J. R. Physiologische untersuchungen über die thierische haushaltung der insecten. Tübingen, I 8 I 7, p. 35-36.

${ }^{31}$ Lintner, J. A. Entomological contributions, 1878 , no. 4, p. 85 (I97).

${ }^{32}$ French, G: H. Larvae of cerura occidentalis Lint., and c. borealis, Bd. (Can. entom., July I88I, v. I3, p. I44-I45.)

${ }^{33}$ Plateau, F. Note sur une sécrétion propre aux coléoptères dytiscides. (Ann. soc. entom., Belg., I876, v. I9, p. I-Io.)

${ }^{34}$ Rougement, P. Observations sur l'organe cétonant du brachinus crepitans Oliv. (Bull. soc. sci. nat. Neuchâtel, I879, v. r I, p. $47 \mathrm{I}-478$, pl.)

${ }^{35}$ Witlaczil, E. Zur anatomie der aphiden.
(Arbeiten zool. inst. univers. Wien u. zool. stat. Trieste, I 882 , t. 6 , p. I-45 (397-44I), 3 pl.) p. I4-I8.

${ }^{30}$ Hagen, H. A. Beitrag zur kenntnis des tracheensystems der libellen-larven. (Zool. anzeiger, 5 April I8So, jahrg. 3, p. I57-I6r.) p. I6r.

${ }^{37}$ Buckton, G : B. Mionograph of the British aphides. Lond., 1876 , v. I.

${ }^{38}$ Gentry, T: G : The use of aphis-excrstion and benefit derived therefrom. (Can. entom., Jan. I 874 , v. 6, p. 5-8.)

${ }^{39}$ Morren, C: Mémoire sur l'émigration du puceron du pêcher (aphis persicae), et sur les caractères et l'anatomie de cette espèce. (Ann. sci. natur., Zool., r836. t. 6, p. 65-93, pl. 6-7.)

${ }^{40}$ Landois, L. Anatomie der bettwanze, cimex lectularius, mit berücksichtigung verwandter hemipterengeschlechter. (Zeitsch. f. wiss. zool., I 868, bd. I8, p. 206-224, pl. I II2.) p. $218-223$.

${ }^{41}$ Aubé, C: [Note sur une sécrétion fétide d'eumolpus pretiosus.] (Ann. soc. entom. Fr., IS37, s. 1, t. 6 ; Bull., p. 58.)

${ }^{42}$ Claus, C. Ueber die wachsbereitenden hautdrüsen der insecten. (Sitzungsber. gesells. z. beford. d. gesammit. naturw. zu Marburg, June i 867 , no. 8, p. 65-72.)

${ }^{43}$ Claus, C. Ueber die seitendrüsen der larve von chrysomela populi. (Zeitschr. f. wiss. zool., I86I, bd. I I, p. 309-314, pl. 25.)

${ }^{44}$ Lyonet, P. Recherches sur l'anatomie et les metamorphoses de différentes espèces d'insectes. Ouvrage posthume, publie par M. W. deHaan, Paris, 1832 .

${ }^{45}$ DeGeer, K: Abhandlungen zur geschichte der insekten aus dem französischen übersetzt ... Nürnberg, I 78 I, bd. 4, p. 386387 , pl. 8, fig. 18-22. [The first edition in French was in 1755. .]

${ }^{46}$ Ratzeburg, J. T. C. Die forst-insekten ... Theil I, Die käfer . . I837, . . p. 246.

${ }^{47}$ Westwood, J : O. An introduction to the modern classification of insects. In 2 vol. Lond. I 839, v. I, p. 388-389.

${ }^{48} \mathrm{Chapuis}$ et Candèze. Catalogue des larves des colèopètres . . (Mém. soc. sci. de

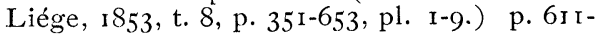
$6 \mathrm{I} 2$.

${ }^{49}$ Klemensiewicz, S. Zur näheren kenntniss der hautdrisen bei den raupen und bei malachius. (Verh. k.-k. zool.-bot. gesells. Wien., I882 [1883], bd. 32; Abh., p. 459-474, pl. 21-22.) 
${ }^{50}$ Aldrovandus, $U$. De animalibus insectis libri septem cum singulorum iconibus ad vivum expressis . . . Denuò impress : Bonon. apud Clementem Ferronium, I638, p. 273. [The first edition was in 1602.]

${ }^{51}$ Goedart, J. Metamorphosis naturalis sive insectorum historia ... Amstelodami, 1700. Pars 2, p. 136. [French ed. of I700,, t. 2, p. 162 ; Lister's Latin ed., Lond., I685, p. 6o.]

${ }^{52}$ Réaumur, R. A. F. Mémoires pour servir à l'histoire des insectes . . . Paris, I736, t. 2, p. 266-269, pl. 21-22. [t. 2, partie 2, p. $2 \mathrm{I}-23$ of the Amsterdam ed. of I 737-I748.]

${ }^{53}$ Meckel, H. Mikrographie einiger drüsenapparate der niederen thiere. (Arch. anat. phys. u. wiss. med., I846, p. I-73, pl. I-3.) p. 46.

${ }^{54}$ Schäffer, J. C. Neuentdeckte theile an raupen und zweyfaltern ... Regensburg, I 754 .

${ }^{55}$ Sulzer, J. H. Die kennzeichen der insekten ... Zürich, 1761, p. $65-67$, pl. 5 , fig. 34 .

${ }^{56} \mathrm{Kirby}$ and Spence. Introduction to entomology . . . 2d ed., Lond., r818, v. 2, p. 238239.

${ }^{57}$ Laboulbène, A. Note sur les caroncules thoraciques ou cocardes rouges du malachius bipustulatus. (Ann. soc. entom. Fr., I858, s. 3 , t. 6 , p. $52 \mathrm{I}-528$.)

${ }^{58}$ Liegel, H. Ueber den ausstülpungsapparat von malachius und verwandten formen. Inaugural-dissertation ... Hannover [? date].

${ }^{59}$ Petzhold, C. P. Lepidopterologische beyträge. (L. G. Scriba's Beiträge zu der insekten-geschichte, Frankfurt am Main, r793, heft 3, p. 230-25r.)

${ }^{60}$ Guenée, A. Dun organe particulier que présente une chenille de lycaena. (Ann. soc. entom. Fr., I867, s. 4, v. 7, p. 665-668, pl. I3, fig. 9-1 2.)

${ }^{61}$ Edwards, W : H : Notes on lycaena pseudargiolus and its larval history. (Can. entom., Jan. I878, v. ro, p. I-I4, fig.)

${ }^{62} \mathrm{Edwards}, \mathrm{W}: \mathrm{H}: \mathrm{On}$ the larvae of $l y c$. pseudargiolus and attendant ants. (Can. entom., July i 878 , v. 1o, p. I 3 r-136, fig. 8.)

${ }^{63}$ Scudder, S: H. Butterflies; their structure, changes, and life-histories ... N. Y., I881, ... p. 26-27.

${ }^{64}$ Gerstaecker, C. E. A. Ueber das vorkommen von ausstülpbaren hautanhängen am hinterleibe an schaben. (Archiv f. naturgesch., I86I, bd. 2I, th. I, p. 107-I 15.)

${ }^{65}$ Brunner von Wattenwyl, K: [Ueber ein neues organ bei den acridiodeen.] (Verhandl. k.-k. zool.-bot. gesells. Wien, I879, bd. 29; Sitzungsber., p. 26-27.)
${ }^{66}$ Schwarz, C. Neuer raupenkalender, ... Nürnberg, I79I. Abth. I, p. 59.

${ }^{67}$ Fitch, A. 8th rept. on the noxious and other insects of ... New York. (Trans. N. Y. state agric. soc., I 862 , v. 22, p. 657-684.) p. 677 [Separate, p. 195].

${ }^{68}$ Coleman, N. Notes on orgyia leucostig. ma. (Papilio, Nov.-Dec. I882 [Jan. I883], v. 2 , p. I64-I66.) p. 165.

${ }^{69}$ Coquillett, D. W : On the early stages of some moths. (Can. entom., March 1880 , v. I2, p. 43-46.) p. 45 .

${ }^{70}$ Dufour, L. Recherches anatomiques sur les carabiques et sur plusieurs autres coleoptères. (Ann. d. sci. nat., I826, t. 8, p. 5-54.)

${ }^{71}$ Müller, F. The habits of various insects. (Nature, I I June I874, v. Io, p. IO2-103, 4I cm.)

${ }^{72}$ Müller, F. Die stinkkölbchen der weiblichen maracujáfalter. (Zeitschr. f. wiss. zool., I877, bd. 30, p. 167-170, pl. 9.)

${ }^{73}$ Müller, F. Beobachtungen an brasilianischen schmetterlingen. 2. Die duftschuppen der männlichen maracujáfalter. (Kosmos, Aug. 1877, bd. I, p. 391-395, fig. 5-6, 174 cm.)

${ }^{74}$ Müller, F. Der anhang am hinterleibe der acraea-weibchen. (Zool. anzeiger, 6 Aug. 1883, jahrg. 6, p. 415-416.)

${ }^{75}$ Doubleday, E: Genera of diurnal lepidoptera, Lond., I846-1850, p. 139.

${ }^{76}$ Rogenhofer, A. Drei schmetterlingsmetamorphosen. (Verh. k-k. zool.-bot. gesells. Wien, I862, bd. I2 ; Abh., p. 1224-123o.) p. 1227 .

${ }^{77}$ Goossens, T. [Sur un organe entre la tête et la première paire de pattes de quelques chenilles.] (Ann. soc. entom. Fr., r869, s. 4, t. 9 ; Bull., p. 6o-6r.)

${ }^{78}$ Lacordaire, $J$. 'T. Introduction à l'entomologie. I838, t. 2 , p. 45 .

${ }^{79}$ Goossens, T. De la corne chez les sphingidae. (Ann. soc. entom. Fr., ז873, s. 5, t. 3 , p. 123-128.)

${ }^{80}$ Bonnet, C: Mémoire sur une nouvelle partie commune à plusieurs espèces de chenilles. (Mém. math. d. savants étrang. Paris, 1755 , t. 2, p. 44-52.) (Collection complète des œuvres de C: Bonnet, t. 2, I779, p. 3-16.)

${ }^{81}$ Müller, F. Ueber haarpinsel, filzflecke und ähnliche gebilde auf den flügeln männlicher schmetterlinge. (Jena. zeitschr. f. naturw., I877, bd. I I, p. 99-I I4.)

${ }^{82}$ Bertkau, P. Duftapparat an schmetterlingsbeinen. (Entom. nachrichten, I Sept. I 879 , jahrg. 5, p. 223-224.) 

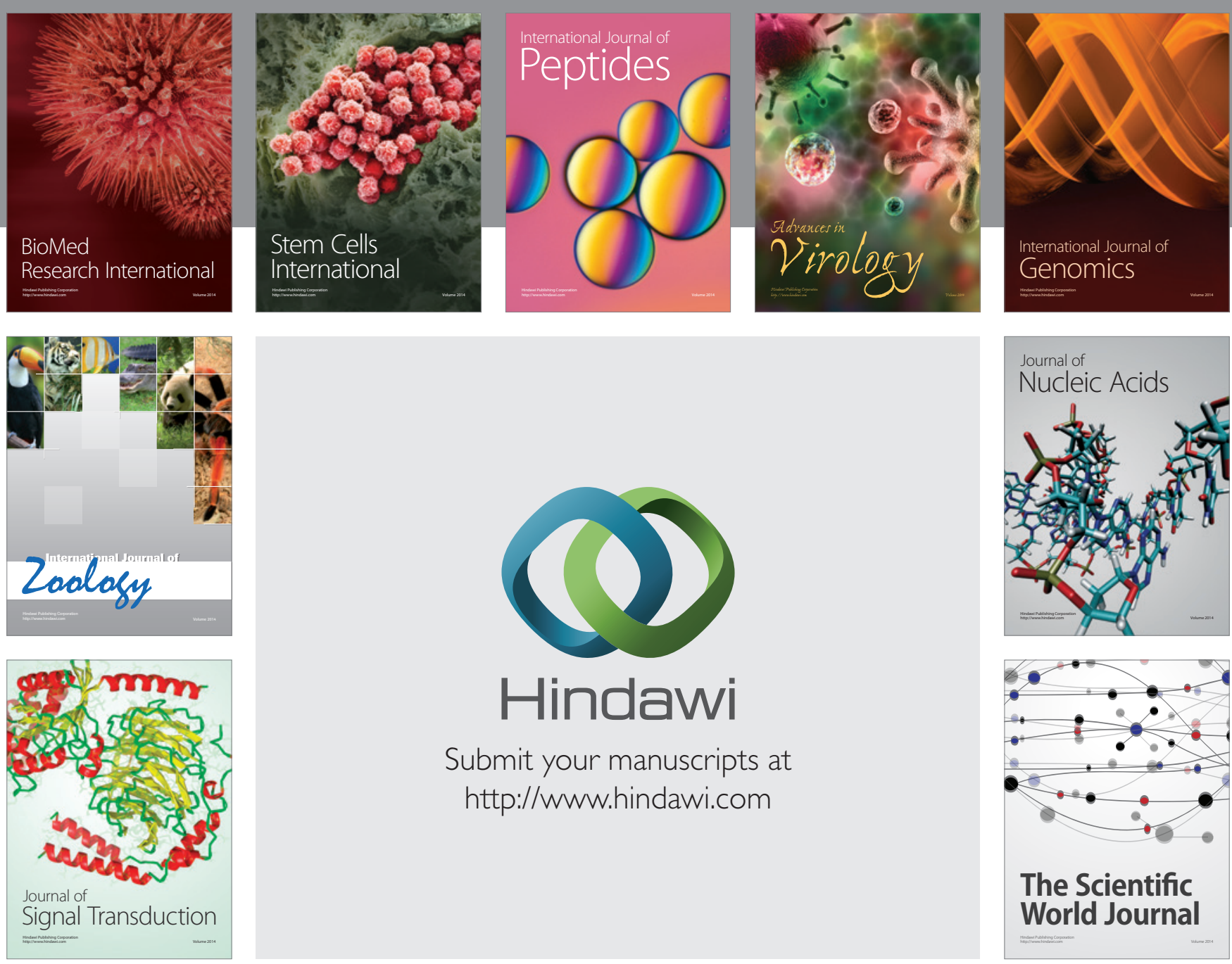

Submit your manuscripts at

http://www.hindawi.com
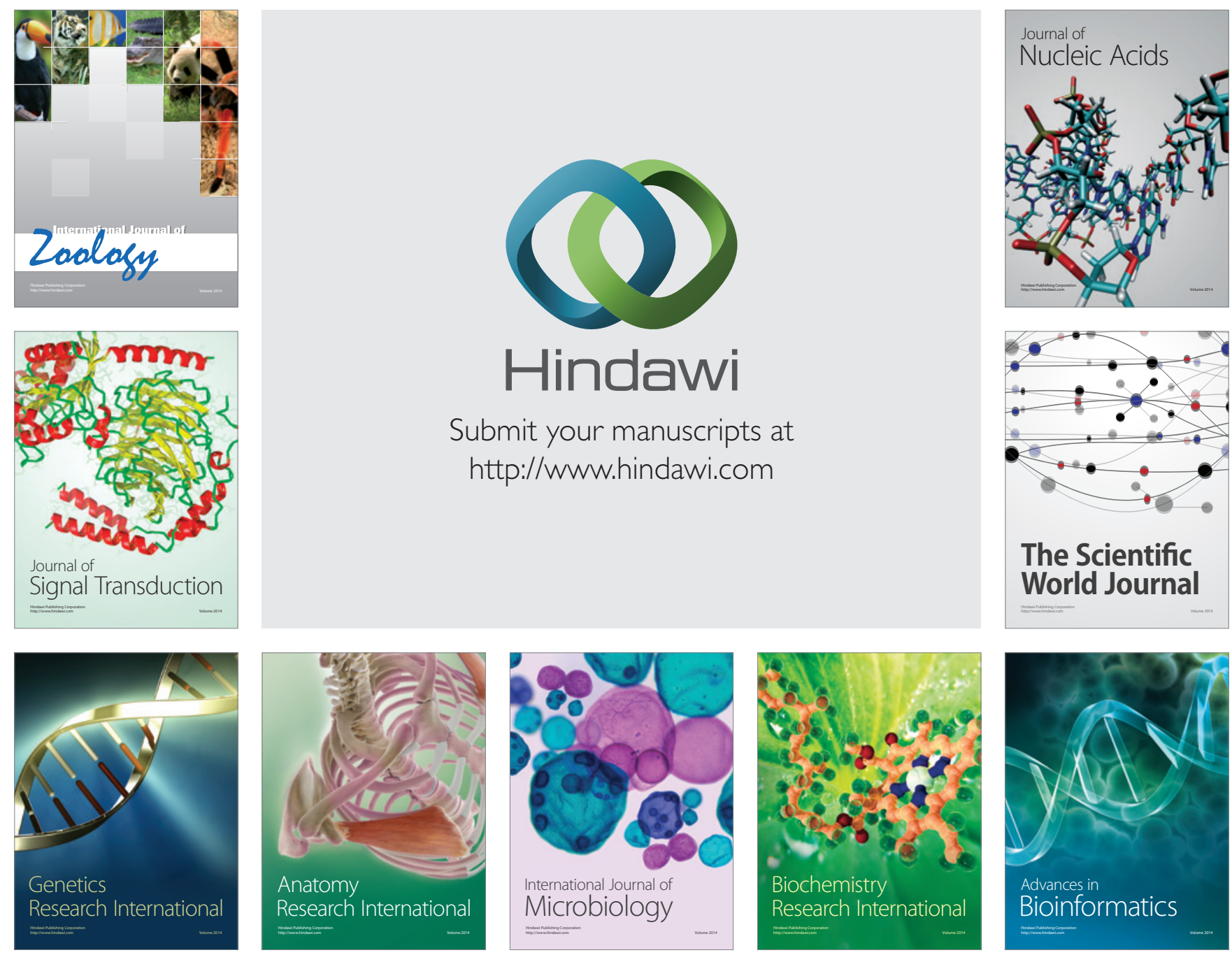

The Scientific World Journal
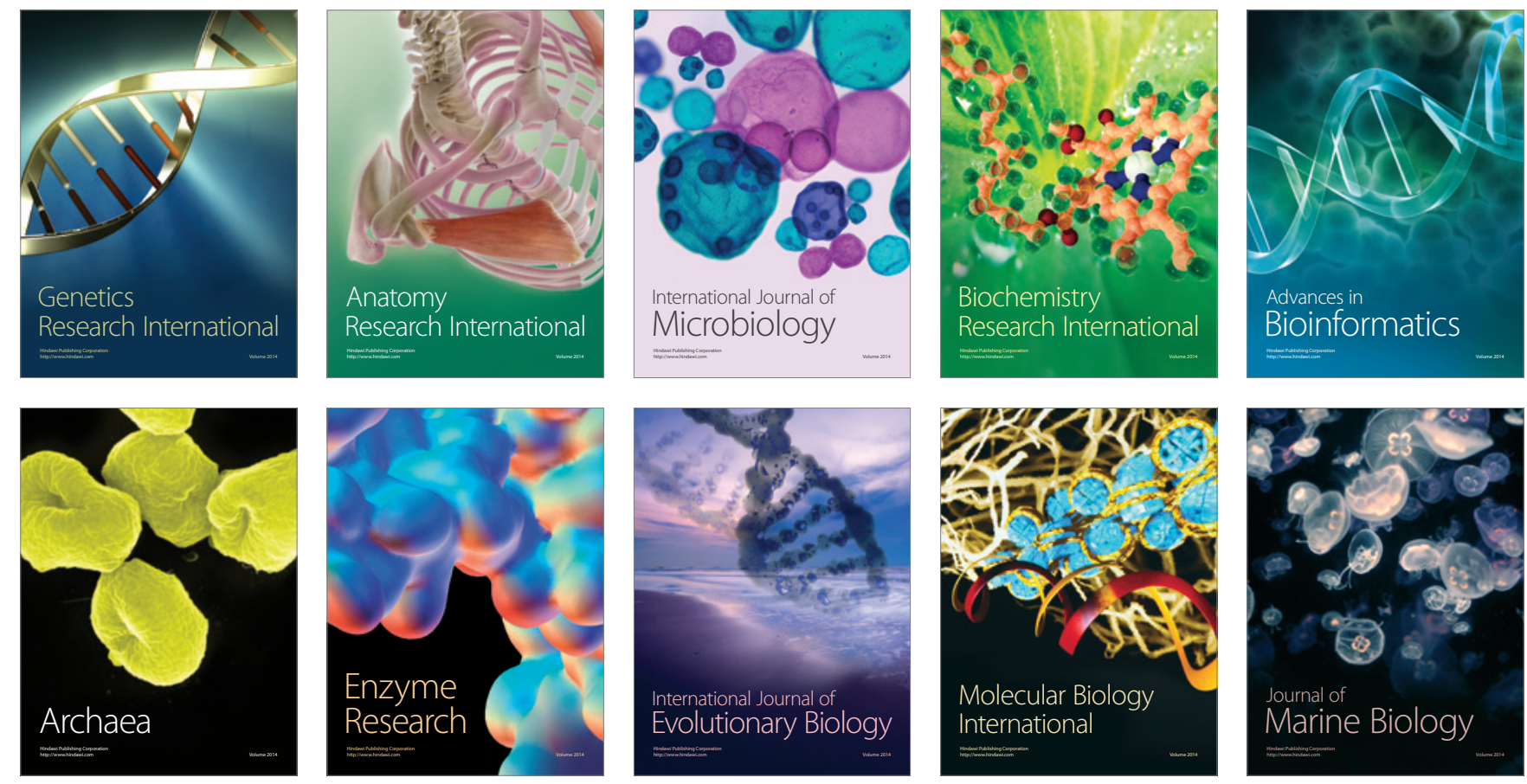